\title{
The position of cooperatives in the new social economy
}

\section{Introduction}

Social economy, as an economic category, can be generally interpreted as a set of principles which define the ways of conduct, taking the initiative and satisfying the needs. The primacy of the individual and the social objective over capital (profit maximisation) is essential; therefore for entities falling into the scope of the mentioned category, widelyrecognised social objective is of an essential significance in line with the economic target. In social economy, as a form of management, the active entities "...are oriented towards the social utility and the surplus earned by them also serves to complete social purposes. Their mission results from and is protected by management autonomy, democratic autonomy of decisions and their local roots" (Sobol 2009 , p. 9). Social economy is based on values of solidarity, participation, autonomous management (self-governance) and it plays a very important role in social development at different levels of management, especially at the local level. As a consequence, it allows to involve human resources in a way which

Prof. Waldemar Czternasty Poznań University of Economics is complementary to public and private sectors, as well as, to influence, in a preventive manner, the economic, social and cultural 
fields, present in every society, that are threatened with marginalization which results in social pathology. Its negative influence can be sensed by the whole society.

The above mentioned values and objectives of social economy are also applicable in a cooperative form of management and they are reflected in its constituent principles and functioning. Therefore the cognitive objective of the paper, in the above context, is to recognise the dependencies between the increase of significance of social economy and cooperative movement dynamism and to specify the trends of its development as well as the conditions that determine those trends. In this light, an important thesis is the statement that contemporary economy trends give the incentive for the development of a mutual (reciprocal) form of management.

\section{The origin of the social economy}

The beginning of the $19^{\text {th }}$ century, with the collapse of the social order created by the development of industrialism and democratic revolution, required changes which could help to solve the difficult situation in those days. Many research areas then made references to social issues. Also a political thought asked a question related to the basics of social life, referred, among other things, to problems regarding the conditions of production or ways of distribution of goods and services.

The social economy, being created at that time, originated mostly from different attitudes to liberal thought and political economy, creators and promoters of which were A. Smith and J. S. Mill. It is them, who, while seeking the solutions of existing economic situation resulting from the disturbed social order, formulated the liberalism foundations.

In the context of the above, one can indicate three social economy trends that were created in the second half of the $19^{\text {th }}$ century (Czternasty 2013, p. 50):

- the first one originated from the liberal thought and recognised social economy as complementary to classical political economy; the first of them was focused on meeting human needs and aspirations in respect of health care, education etc.,

- the second trend developed in the socialist current which opposed the classical political economy; it focused particularly on social life organising and operations in favour of all society and not individuals only,

- the last one took its origin from Christian vision, referring to such organisation of work which protects all society as well as equality and freedom of each individual. 
The social economy and various issues related to it are shown in the economic literature of the second half of the $19^{\text {th }}$ century and in the economic life of that time. For instance, with L. Walras, the social economy became a part of the theory of economics and that, in turn, was treated as a science of social wealth distribution that addresses pure and applied economy and social economy. The presence of this economy can be also noticed in the literature of communist movement. For example K. Marx in his work shows a collective form of management (cooperatives) which he regards as a way to free the working masses; however, a bigger emphasis was put on their political self-organisation and that was what he particularly recognised in reality.

A group of Utopian socialists must also be mentioned. They were supporters of so-called a cooperative socialism. In France, K. Fourier saw the practical solutions of social economy in reciprocal societies, completely, or at least to a big extent, self-sufficient, which organised work and consumption. In turn, R. Owen operating in Britain "feeling" the idea of social economy, suggested, among others, the concept of organising production associations (communes, communities) with egalitarian or proportional share to the individual members' contributions (quoted in: Boczar 1979, p. 50). On must also refer to W. King, a publisher and editor of the "The Co-operator" - a monthly periodical. His ideas aimed at full elimination of private-capital profit by allocating all the surplus earned by the associations to meet their members' needs, excluding any interest rate on capital.

Once again social economy reawakened in times of so-called Great Depression in the beginning of 1930s. For example, in France, despite the harsh economic and social condition, the cooperative movement functioned without major problems. It inspired the reflections on co-operative economy advantages and drawbacks of the capitalist system. A fundamental quality of collective management was noticed, which is convergent with currently promoted idea of social economy - connecting the economic and social aspect. G. Fouquet (citing from Kaźmierczak and Rymsza 2007, p. 97) described it as follows: "the capitalist and market based economy (...) has gradually detached the economic from the social and thus, given birth to hard realities that served as a model for the abstractions of economists. Conversely, the cooperative institutions, by restituting to the associates the function that the salesman had taken away, reintegrate the economic into the social". Perhaps, this direction of development consistent with the cooperative vision would be sustained if J. Keynes did not appear. J. Keynes in his works started the thought of state interventionism and the welfare state doctrine. Consequently, the social economy lost its prominence 
and paled into insignificance for many decades. No sooner than in 70s and 80s of the $20^{\text {th }}$ century it reawakened. In terms of: local economy, solidarity, alternative or social enterprises it appeared not only in European countries but also in Canada and the United States of America.

It should be stressed that the "old" social economy focused on problems regarding the elimination of exploitation and alienation through farming in collective forms of ownership - cooperatives, associations, repri mutual help society; its main objective was to weaken the social (class) conflicts.

\section{The idea and objectives of social economy}

A modern concept of social economy was adapted on the state level in 1980 by the French government and then by other highly developed countries. Departments and offices responsible for that aspect of state activity were created. Generally, in papers released by various bodies of the European Union or other international organisations there are clear references to the concept and institution of social economy.

The primacy of the individual and social objective over capital (profit maximisation) is essential; therefore for entities falling into the scope of the mentioned category the widely-recognised social objective is of an essential significance in line with the economic target.

Therefore, a question of a significant interest in social economy in modern, well-developed economies occurs. There are many reason of such interest. Among those reasons a special emphasis is necessary when considering: present globalisation processes, the welfare state crisis in Western Europe, the dissolution of the Soviet Union, a recent economic crisis etc. It should be noted that more and more frequently standard actions of employment services and social welfare appear to be insufficient, while the public sector becomes more and more incapable to bear costs of social benefits. One can observe a more and more common tendency of switching from the model of a welfare state to the welfare society model. Such a change, which is to take place in Poland in future economy reality, is indicated in Poland 2030 Report (Wygnański 2009, p. 9).

The growth of the significance of social economy should also be connected with the unemployment, which is, among others, the result of the above mentioned process of globalisation that generates changes in the labour share (contribution), in respect of social as well as territorial issue. It is known that the unemployment is frequently reflected in social exclusion, an increase of social inequalities, permanent poverty growth in excluded groups of middle class, 
magnifying the uncertainty and risk etc. These arguments clearly indicate the need of the social economy development even in highly developed countries.

The above mentioned exhaustion of welfare state possibilities is a significant argument. It results from financial matters - costs of welfare in many cases are too high, impossible to bear by national economies. Also the market, including a labour market, is excluded from the efficient influence of the state. Consequently, the mentioned reasons generate the need to reorient the social policy. This policy should undertake such actions which would counteract the unemployment, poverty and exclusion and which would help the unemployed people to return to the labour market. It should be done by the actions oriented towards an active search of work and opportunities to obtain it (Kaźmierczak and Rymsza 2007, pp. 98-103).

According to and resulting from the above remarks, economic and social problems of states, despite the welfare level or political system, force finding new solutions, many of which are related to the idea of social economy. It represents an active - not demanding - attitude to private interests and being directed towards problem solving of wider social groups it also attempts to realise them not individually but in mutual cooperation, basing on fundamental principles of the social economy: solidarity and cooperation, opposing the market competitiveness. Other principles, characterising that point of view and actions, are, among other things:

- entrepreneurship and commitment, without which the functioning of social economy entities would not be possible; since that kind of social activity bases on people who want to cooperate, get involved in favour of a common good, who trust one another and thanks to it they are willing to take the risk in the name of common interests,

- subsidiarity and solidarity which are the foundations of such organisation of work and responsibility so that the largest group of people interested in it, for whom those actions are carried, could take part in the planning, realisation and evaluation process of undertaken actions,

- prudence and responsibility, which say that common actions based on principles mentioned above, are not yet the success but any individual form undertook consciously and responsibly (for instance consumer conscious actions); in social economy the activity of an individual is extremely important; consumer, investor, citizen,

- independence and empowerment which exceeded exclusively privileging the profit; they give a chance to protect sovereignty and empowerment of individual people, groups and institutions. 
The sense of social economy can be summarised by describing chances which it provides for various individuals and groups (Wygnański 2009, pp. 5-7):

- for the individuals it provides a chance to act and care independently for themselves and their relatives by gaining the opportunity to achieve incomes from work which, in consequence, means performing actions which let them function and regain the sense of self-respect and dignity,

- for organisations it provides a chance to switch from the "demanding hand" scheme, being dependent on public or private interests, to separation and ability to act according to their own mission,

- for the communities it shows the perspective to build independent development strategies which are based on own resources and they implement genuine selfgovernance, trying to win the welfare of the citizens.

The social economy is not a separate branch of economy but it is its inner part which covers a triangle, which sides are determined by: market economy, civil society and democratic state. Its concept, as it was noticed above, is wide an covers a lot of social life issues, however, the linking elements for sure are the actions which concentrate on satisfying the needs of society.

The specific nature of the social society consists in the fact that the objectives as well as the ways to control the entities are all social. The field of functioning covers mostly that part of social problems which the public sector cannot cope with and the private sector is not interested in investing in because very often it is not the activity which generates permanent profits. By solving or soothing social problems, social economy is not of an alternative character to private economy, it is also not competitive for state economy but it is complementary to the market and the state (supplementing it) and it can also make a major contribution towards a sustainable socioeconomic development (Hausner 2007).

The sector of social economy implements its tasks through those economic entities which are characterised by a social objective and which are not directed towards the creation and distribution of capital and they, as well, have a democratic and tangible structure based on shared management (Pearce 2003, p. 6). The entities of the social economy sector are characterised by a big variety of legal forms and different stress on economic and social issues in their mission (see diagram 1). Those varied organisational forms and objectives of individual economic entities are reflected in the necessity to include practically each of them in separate frames which shape their activity. One can indicate such enterprises of social economy which fundamental function is conducting the economic activity and social objectives are performed through the financial surplus; one can also distinguish the entities which do not conduct the economic activity 
and which are supported by subsidies or donations and those which conduct an economic activity to a limited extent. Therefore, the significant directions of the development of social economy entities are - as it is emphasised in the literature - "economisation" of social targets or "socialisation" of economic targets (Sobol 2009, p. 7).

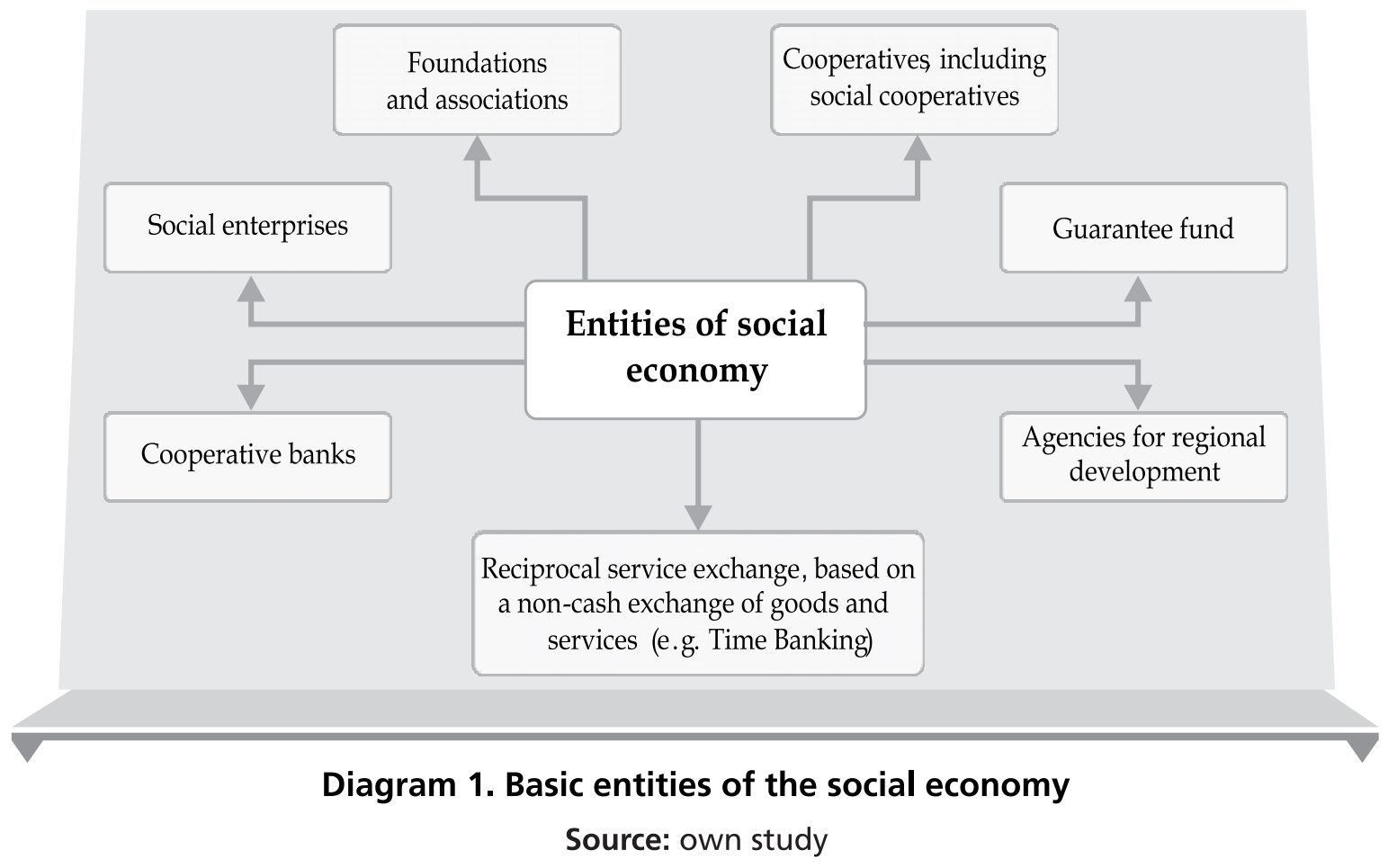

EMES International research network which popularises the problems of different aspects of conduct of social enterprises distinguishes, among others, the economic and social criteria which should characterise the initiatives of social economy. The first ones include:

- a continuous regular activity based on economic instruments,

- autonomy, sovereignty and independence from public authorities,

- bearing a significant level of economic risk,

- a minimum amount of paid work.

The indicators which describe the social dimensions of such enterprise are as follows (Sobolewski, Klimek, Piekutowski 2009, p. 8): 
- an explicit aim to benefit the community,

- an initiative launched by a group of citizens or civil society organizations,

- a specific, if possible democratic, system of management,

- a cooperative character of functioning,

- a limited profit distribution.

The above set of criteria should be regarded as the one that defines the definition of an ideal social enterprise. In practise it is required that an organization should meet most of the presented conditions to qualify as a social enterprise. These conditions are met by social entities in the context of the idea that they are characterised by.

\section{Constitutive principles and cooperative values}

In theory, as well as on business practice grounds there are some permanent, constant, constitutive features of a collective form of management which are linked with the society and directly economic character of cooperatives. The first of the mentioned features should be complementary treatment of economic and social objectives; this follows the fact that the entity restricting its activity only to the business domain cannot be regarded a cooperative. Obviously the essence and contents of those objectives captured separately and the ratio and interdependences between them are controversial but they always have to coexist.

Another constitutive value of cooperatives can be regarded the democratic management and control which means, among other things, the appointment by the members of associations their managing bodies which also monitor main activities, the responsibility of cooperative authorities to members, an equal vote of individual cooperative members ("one member - one vote"), the opportunity of an actual individual participation in management and monitoring the cooperative's activity.

Next constitutive characteristic of cooperatives is the solution which in a figurative sense can be described as follows: cooperatives are run by people, not money. It means, inter alia, that members decide how to allocate profits (surplus) and savings from previous financial years (if necessary how to cover the losses), what share is reinvested in the business to fund future developments, for common use or allocation amongst members or such allocation of a determined part of the surplus so that no member can benefit over the others. This allocation is supposed to create a co-dependency between the cooperative prosperity and the contentment of the members and 
uniformity in benefit shares dedicated to each individual member (Czternasty i Kujaczyński 1994).

One should also notice the principles which result from the social-collective character of management: voluntary and open membership and conducting educational activity. The first principle means that the creation or dissolution of cooperatives is a reflection of the free will of a specified group of natural or legal persons while leaving the cooperative is dependent upon the decision of particular member; therefore there cannot exist any administrative or other pressure questioning the principle of voluntary membership. It corresponds directly with the principle of open membership ("the open door"). It means that there is no artificial barrier or discrimination obstacle in connection with the social, political, race or religious issue for anybody who wants to take on the duties and responsibilities regarding the membership and to keep so-called cooperative loyalty reflected (in some groups or types of cooperatives) in a close economic and social cooperation between the members and the organisation. It should be also noted that the need of educational activity, embedded in the functioning of collective entities, resulting from principles of cooperatives, is reflected in, among others, a systematic opportunity for members to become acquainted with the principles (rules) and techniques of cooperatives functioning on the economic grounds and in the scope of democracy which characterises the collective form of management. There are also cultural and educational activities available among the members and the environment of people potentially interested in cooperatives (Czternasty 2013, pp. 19-22).

The presented ideas of a collective movement and its values and principles convince that the collective form of management can be an alternative to the commercial economy privileging the profit as it is in its nature, pro-social and financially more ethical. Its values, at the same time, place it in a domain of economy which can be close to many people by creating the opportunities to be active professionally and socially while in market economy (which gets stronger and stronger) it may prevent social exclusion, neutral various kinds of pathologies, give the sense of security stability. It also releases individual and collective entrepreneurship.

\section{Development opportunities of the cooperative management - in the context of social economy creation in Poland}

The creation of cooperative movement, which represents, as it was pointed out above, a form of an economic and social activity of a group of people aiming at 
realisation of common objectives, was mostly connected with the protection of economically weak people who were not able to function in the economic reality, unable to oppose the market requirements so it was of a social character. The cooperative movement, as a historical and transinstitutional phenomenon, was subject to constant evolution generated by the development of economies and societies and by the appearance of new economic and social problems which could be solve within cooperative forms.

The changed economic reality in Poland after 1989 - democratisation of the country, entering the market economy, pluralism of the ideology etc. - should create, as it can be assumed, such a set of norms and regulations of management which would secure the functioning of the entities of various ownership forms. Therefore there should be favourable prerequisites to re-awake the cooperative movement and to restore the balance between a social and economic character of cooperatives which was disturbed in 1945-1989, the reactivation of the authentic cooperative ownership and disclosure of its potential advantages and possibilities (Czternasty 2011, pp. 91-92). Especially that those actions fit in a cooperative policy of the European Union which recognizes and promotes the socioeconomic significance of the collective management (Cooperative Europe, p. 15). It should mostly consist in:

- the co-creation of a local market and its infrastructure in the manner which allows to protect the interests of the members, to sooth the negative results of market economy, especially to oppose the economic and social inequalities and to protect members against aggressive actions of various economic entities,

- to fulfil its role in an effective integration of financial means of the citizens to realise common objectives satisfying specified needs of family households of cooperatives' members,

- enriching the pluralism in economy, playing a role of a balancing power due to conducting the activity aiming at satisfying the needs of specified groups of society being members of the cooperatives - apart from the entities which are driven by the profit maximisation,

- opposing social disintegration, especially in local rural societies (in villages and small towns) or of some social groups, enriching them with elements of democracy and social solidarity (Dyka and Grzegorzewski 2010, p. 16).

A particular utility of cooperatives development in rural areas is worth stressing (Czternasty and Czyżewski 2007, pp. 230-231). It can not only improve the standing of homesteads but also to shape many other economic and social benefits for all local community which can, among other things, be reflected 
in so-called social cooperative pension which expresses the effects of the cooperative as an association.

The above remarks induce a question whether the arguments pointing out the necessity of the development of a cooperative management can be completed in the economic reality? In other words whether the cooperatives in Poland under the market economy realities can function and develop and alongside fulfil the assigned specified functions.

The positive answer should particularly emphasise the fact that the term social economy becomes more and more popular in Polish society; at the same time Poland has rich traditions of social economy implementation (which go back to the $19^{\text {th }}$ century). The practical reflection of that phenomenon is the perception of some social groups of the sense as well as economic and social effects of collective management following the solutions from the past and solutions characteristic for highly developed countries. Unfortunately, this perception is still limited. It mostly concentrates on one form of collective activity - social cooperatives. The legislative acts, among others, the Act of 27 April 2006 on Social Cooperatives and its important amendment of 16 July 2009. It must be understood that it gave the legislative basis to conduct a collective entity for people at risk of social exclusion - unemployed, homeless who implement an individual programme of working their way out of homelessness, alcohol dependent (addicts) after the psychotherapy programme, people addicted to drugs or other intoxicants after termination of a therapeutic programme, people with mental diseases, people released from penitentiaries or prisons who have problems with social inclusion, refugees implementing an individual integration programme or disabled and handicapped people. Undoubtedly, those groups would have difficulties in starting and conducting individual economic entity. Hence, by creating jobs for themselves and being personally involved in conducting a social cooperative the members provide incomes for themselves and their families and through a collective actions they change not only themselves but also the environment in which they function. Apart from a common management of the entity, specified social objectives are also implemented. Therefore in social cooperatives the social and professional (vocational) reintegration of the members takes place which, in accordance with the Act, is described as "a reconstruction and maintenance of members' participation (...) in local community life and playing social roles in workplace, place of residence or of a permanent address (...), a reconstruction and maintenance of the ability of work performance on labour market" (Czternasty 2011, pp. 51-52). 
The development of cooperative movement in Poland, its entities included in social economy, cannot be restricted only to a currently preferred form of social cooperatives, among other things, through various obligatory and optional support forms, as well as the information support. Non-governmental organisations (foundations, associations) supporting social economy policy, territorial self-governments, poviat labour offices, labour clubs, social integration centres should stimulate the functioning and development of various cooperative bodies.

It should be noted that after 1989 approximately $45 \%$ of different cooperatives in Poland got closed down, their assets, properties and jobs were lost and the share of cooperatives in Gross Domestic Product (GPD) creation declined. Three branches: dairy industry, housing industry and cooperative banks retained a relatively strong position. Favourable legislative solutions caused a fast development of credit unions. One can also distinguish a cooperative group which aims at retaining and maintaining their assets and possessions and which slowly but steadily without unnecessary risk develops their current activity. They do that to keep their market position, mostly local. In those entities there are correct relations between the members and the cooperative, the financial results are sufficient and cooperative assets and possessions are used properly (Brodziński 2005, pp. 164-165).

The opposite pole represents quasi-cooperatives which economic standing is very poor and which do not aim at winning new members. They often implement the policy of limiting their economic activities. It is supposed to lead to enfranchisement and, consequently, to the division and distribution of cooperative assets and possessions among a small number of interested individuals. Also it is necessary to point out that in Polish economy there is a group of economically relatively weak cooperatives which is characterised by an increasing discouragement of the members towards the cooperative management. Those members wait for the amendment of cooperative legislative acts to convert the cooperatives into other legal entities which bring better economic performance.

The last two groups of cooperatives hardly function in the field of social economy. Their characteristic feature, as it was emphasised on numerous occasions, is the implementation of a social mission in line with economic objectives. They just demonstrate an existing lethargy in the field of re-awaking and popularisation of cooperative social values. In many cases it also presents an insufficient control (monitoring) over observance of cooperative principles. The tendency of departing from cooperative democracy principles and supporting 
the evolution of cooperative entities towards the capital direction is still present. Whereas, as it was emphasised several times already, the actual economic needs and social problems simply provoke to reach for historically tested methods of cooperative activity.

Where does the collective management then, find the basis to develop? There, where the market economy state demonstrates protective features, creates the "primary ground" for the development of various management forms (e.g. Denmark, France, the Netherlands, the United Kingdom), where the social economy is fully implemented and which can oppose the commercial economy. The creation of a strong sector of social economy can restrict the influence of the latter on social relationships, partnership, activity, democracy etc. (KRS 2006).

\section{Conclusions}

Treating the cooperatives as the entities of social economy, which follow constitutive principles, the ideas and values of cooperative entities requires a constant stimulation of the cooperative movement by state policy. It enables the movement re-creation and development and in accordance to the actions of other EU member states it also allows to limit the social exclusion and inequalities in the society. The following actions, in that field, seem indispensable:

- restoring economic relationships - they are reflected in legal changes referring to the tax and financial system to restore specific solutions for the whole sector of social economy (not only social cooperatives exclusively) which is focused not only on the profit,

- reconstruction of social resources, restoring cooperative bonds, strengthening the position of cooperatives and cooperative movement on the opinion market,

- transposition of positive patterns and solutions in the field of social economy and its entities development from highly developed countries, members of the European Union,

- stimulation and supporting various initiatives referring the creation of new solutions and cooperative management under social economy,

- promoting an active participation of local self-governments in actions for social economy - e.g. through the creation of social economy incubators, a conscious purchase of services, promotional services for entities, using instruments of social economy in strategic planning of a local development (Czternasty 2011, p. 53). 
These mentioned and other actions, included in the implementation of social economy will enable to build economic solidarity, collective resourcefulness of cooperatives as the institution of that economy, their reciprocal cooperation etc.

\section{Summary}

The position of cooperatives in the new social economy

A dynamic development of market economy, broadly understood globalisation, the welfare state crisis in Western Europe etc. cause the intensification and creation of new aspects of poverty, marginalisation and social exclusion. The capabilities to solve the increasing social issues must be connected with the idea of social economy which assumes, among other things, facilitating the employment participation, access and use of any resources, laws, products and services. The opportunities of implementing those actions are linked to functioning of a specific group of entities which perform, along with the economic activity, also a social mission. Cooperatives should be classified in such group. They can be an alternative for those entities of commercial economy which are profit-oriented. Hence, the aim of this paper is to identify the interdependencies between the increase in significance of social economy in market economies (inter alia in Poland) and the pace of development of cooperative movement, indicating its directions the conditions that determine it.

Key words: commercial economy, cooperative movement, social economy, social mission of the state, social economy entities.

\section{Streszczenie}

Miejsce spółdzielczości we współczesnej ekonomii społecznej Dynamiczny rozwój gospodarki rynkowej, szeroko rozumiana globalizacja, kryzys państwa opiekuńczego w Zachodniej Europie itp. powodują potęgowanie się i pojawianie nowych aspektów ubóstwa, marginalizacji, wykluczenia społecznego. Możliwości rozwiązywania narastających kwestii społecznych łączyć należy z ideą ekonomii społecznej zakładającą m.in. ułatwianie uczestnictwa w zatrudnieniu, w dostępie i korzystaniu z wszelkich 
zasobów, praw, produktów i usług. Możliwości realizacji tych działań wiążą się z funkcjonowaniem pewnej grupy podmiotów wykonujących, obok działalności gospodarczej, misję społeczną. Zaliczyć do nich należy spółdzielnie. Stanowić mogą one alternatywę wobec nastawionych na zysk podmiotów gospodarki komercyjnej. Stąd, jako cel opracowania przyjęto rozpoznanie zależności pomiędzy wzrostem znaczenia ekonomii społecznej w gospodarkach rynkowych (m.in. w Polsce) a tempem rozwoju ruchu spółdzielczego, wskazując zarazem na jego kierunki i determinujące go uwarunkowania.

\section{Słowa}

kluczowe: ekonomia komercyjna, spółdzielczość, ekonomia społeczna, misja społeczna państwa, podmioty ekonomii społecznej

\section{References}

1. Boczar K. (1979), Spółdzielczość, PWE, Warszawa.

2. Brodziński M. G. (2005), Spótdzielczość obstugująca wieś i rolnictwo w okresie przeksztatceń ustrojowych, Wyd. Wyższej Szkoły Ekonomicznej, Warszawa.

3. Cooperative Europe, CSR Co-operative Social Responsibility, wydanie elektroniczne, www.coopseurope.coop/about-us, 20.03.2013 - data dostępu.

4. Czternasty W. (2013), Determinanty rozwoju spótdzielczości w różnych warunkach ekonomiczno-społecznych, Wydawnictwo Adam Marszałek, Torun.

5. Czternasty W. (2012), Spótdzielczość versus nierówności ekonomicznospołeczne, w: A. Czyżewski, A. Matuszczak (eds.), Ekonomia i jej społeczne otoczenie, Wyd. Kujawsko-Pomorskiej Szkoły Wyższej, Bydgoszcz.

6. Czternasty W. (2011), Wspótczesny obraz spótdzielczości w Polsce determinanty jego powstania oraz zmian, w: K. Pająk, A. Przymeński (eds.), Polityka społeczna w realiach gospodarczych Polski po 1989 roku, Wyd. Uniwersytetu Ekonomicznego w Poznaniu, Poznań.

7. Czternasty W., Czyżewski B. (2007), Struktury kierowania agrobiznesem $w$ Polsce, Wyd. Akademii Ekonomicznej w Poznaniu, Poznań.

8. Czternasty W., Kujaczyński T. (1994), Dostosowania spótdzielczości w różnych ustrojach gospodarczych, referat na seminarium "Co-operatives Development Strategies”, Spółdzielczy Instytut Badawczy, Kraków.

9. DykaS., Grzegorzewski P. (2010), Zarzadzanie spótdzielnia, Difin, Warszawa.

10. Hausner J. (ed.) (2007), Ekonomia społeczna a rozwój, Małopolska Szkoła Administracji Publicznej, Kraków.

11. Kaźmierczak T., Rymsza M. (eds.) (2007), Kapitat spoteczny, ekonomia społeczna, Instytut Spraw Społecznych, Warszawa. 
12. Pearce J. (2003), Social Enterprise In Anytown, Ca-lauste Guntelkian Fundations, London.

13. Sobol A. (2009), Społeczne aspekty działalności spótdzielni socjalnych, Wyd. Krajowej Rady Spółdzielczej, Warszawa.

14. Sobolewski A., Klimek P., Piekutowski J. (eds.) (2009), Ekonomia społeczna $w$ kreowaniu polityki lokalnej gmin i powiatów, Stowarzyszenie Czas Przestrzeń Tożsamość, Szczecin.

15. KRS (2006), Uwagi i propozycje Krajowej Rady Spótdzielczej do Narodowego Planu Rozwoju na lata 2007-2013, (2006), Krajowa Rada Spółdzielcza, Warszawa.

16. Wygnański K., (2009), O ekonomii społecznej - podstawowe pojęcia, instytucje $i$ kompetencje, Zachodniopomorska Biblioteka Ekonomii Społecznej, Szczecin. 